\title{
Field evidences of secondary surface ruptures occurred during the 20 February 1956 Eskişehir earthquake in the NW Anatolia
}

\author{
FARUk OCAKOĞLU* and SANEm AÇIKAlin \\ Eskişehir Osmangazi University, Department of Geological Engineering, Eskişehir, Turkey. \\ *e-mail: focak@ogu.edu.tr
}

\begin{abstract}
Surface rupture and source fault of the 20 February 1956 Eskişehir earthquake have been a matter of debate that potentially contributes towards the understanding of the active deformation and seismic risk in the highly populated NW Anatolia. Field observations on the two fault segments (namely Kavacık and Uludere faults) in the north of the Eskişehir graben revealed evidences of co-seismic surface rupture and mass movements during the Eskişehir earthquake. Surface rupture was observed as a $2.5 \mathrm{~m}$ wide, a $100 \mathrm{~m}$ long and ca. $20 \mathrm{~cm}$ deep asymmetric depression in the Gümüşlü valley, $2 \mathrm{~km}$ east of the Uludere village. A trench dug on this depression confirms a prominent high-angle south dipping fault (dominantly left lateral strike slip) and two faint north-dipping antithetics as clear noticeable shear zones in organic-rich thick soil. Mass failures are particularly observed in spring depressions filled with loose torrent and carbonaceous material in front of the fault scarp. Some rock slides of several tens of meters in size that obviously require significantly high ground shaking were also developed on steep fault scarps. The orientation of the principal stress tensor as deduced from the surface rupture of the Eskişehir earthquake displays clear inconsistency with the geometry of prominent faults in the area. We concluded that this disagreement may be explained by a curved surface rupture. The western and eastern tips of this rupture are EW trending and the probable NW-running part in the middle would correspond to the bounding zone between two right-stepping faults.
\end{abstract}

\section{Introduction}

The Eskişehir fault zone (also known as İnönüEskişehir fault zone) is a major dominantly dip-slip deformation belt extending from Bursa to the north of Cihanbeyli (figure 1). There is considerable volume of work addressing the morphotectonic history of this zone. In the west where the Eskişehir fault zone joins the intracontinental megashear north Anatolian fault zone, its history extended back to late Oligocene exhumation of the Uludag massif (Okay et al 2008) and the ensuing compressional tectonics (Yaltırak 2002). Towards the SE tip, although a dip-slip component is obvious in Quaternary, a highly complex deformation history of the zone was observed by earlier researchers (Özsayin and Dirik 2007). This fault zone is bifurcated into northern and southern strands to form the symmetrical Eskişehir graben (figure 2; Koçyiğit 2000, 2005; Ocakoğlu 2007). As indicated by many morphotectonic studies and the seismic activity, the Eskişehir graben and its vicinity are actually undergoing a NNE-trending extension (Altunel and Barka 1998; Kahle et al 1998; Tokay 2001; Koçyiğit 2005; Ocakoğlu 2007; Ocakoğlu and Açıkalin 2009). The 20 February 1956 Eskişehir earthquake $\left(M_{\mathrm{w}}=6.5\right.$; Kiratzi 2002) is the modern seismic evidence of this deformation, though its surface rupture, if occurred, has not been convincingly documented

Keywords. Eskişehir fault zone; 1956 Eskişehir earthquake; morphotectonics; surface rupture; NW Anatolia. 


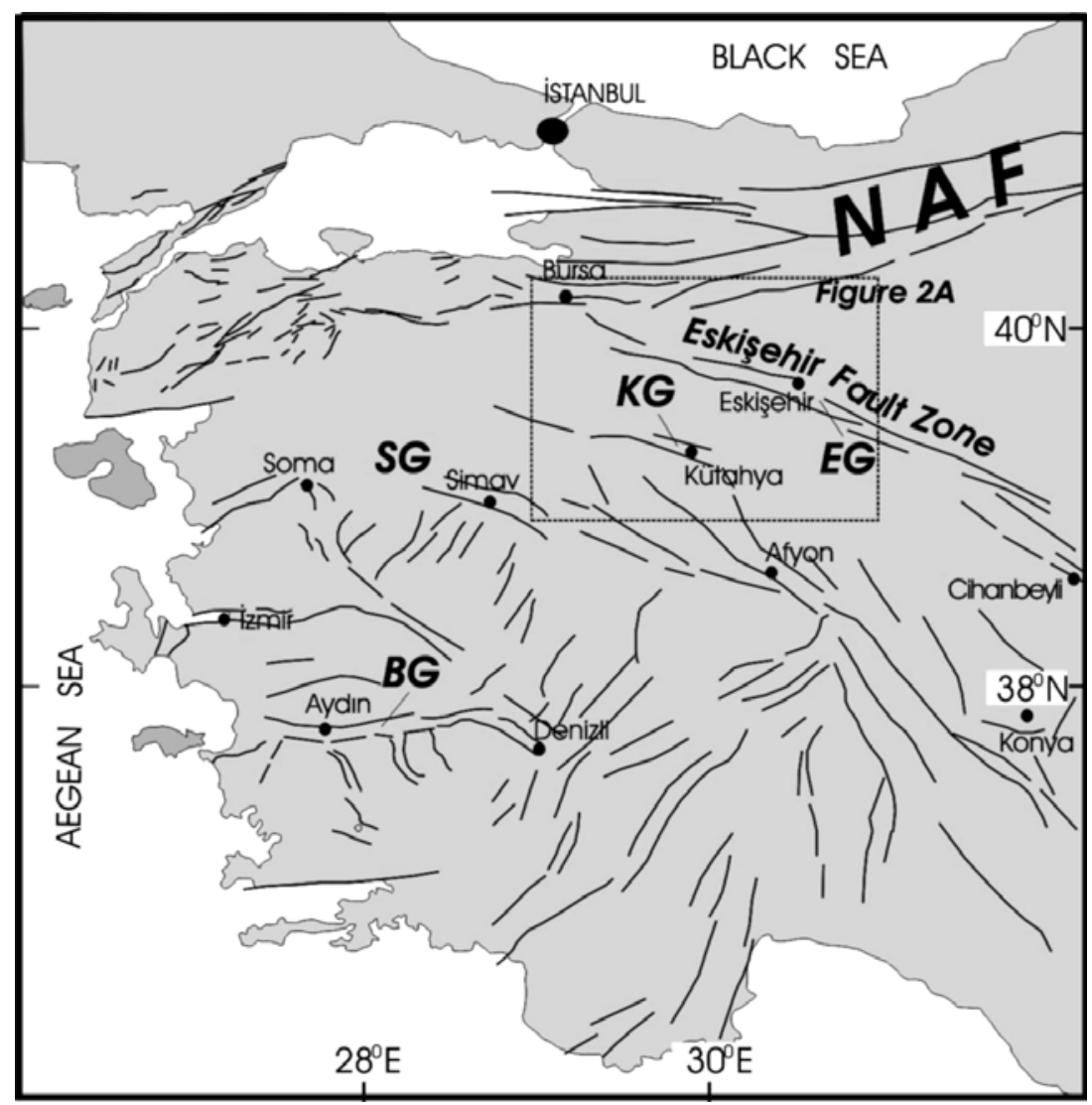

Figure 1. Regional map showing the active faults in Western Anatolia. BG: Büyük Menderes graben; EG: Eskişehir graben; KG: Kütahya graben; NAF: North Anatolian Fault Zone; SG: Simav graben; data from Bozkurt (2001) and Yaltırak (2002).

up until now. McKenzie (1972) studied the focal solution of the Eskişehir earthquake, and concluded that it is related to a dip slip faulting with significant strike-slip component. Altunel and Barka (1998) suggested that a southern segment between Çukurhisar and Eskişehir would have been ruptured during the earthquake. Koçyiğit (2005) accepted this view estimating stress directions from slip measurements in the main bounding faults in this area, and the focal solutions of McKenzie (1972). Şaroğlu et al (2005) located the ruptured segment further west (İnönü area) where the fault morphology is most prominent. Açıkalın and Ocakoğlu (2005) analyzed the damage data given by Öcal (1959), and showed that maximum damage rate was centered on the northern part of the graben (figure 3). Later Ocakoğlu et al (2005, 2006) used several attenuation equations to model the areal distribution of possible damage resulting from earthquakes from different active faults in the Eskişehir region. They identified a strong correlation of damage rates in relation to 20 February 1956 earthquake with the Kavacık Fault in the north of the graben.

The present paper substantiates for the first time the evidence of surface rupture and mass-failures in relation to the 20 February 1956 earthquake from the northern part of the Eskişehir graben. We give here a brief morphotectonic account of the mountain-front where the surface rupture occurred. After evaluating the surface rupture and earthquake triggered landslides, we discuss the previously collected data and its correlation with our present observations.

\section{Morphotectonics of the Kavacık and Uludere segments}

Ocakoğlu et al (2005), first defined the EW trending Kavacik and Uludere fault segments as right-stepping presumably dip-slip faults that border the Eskişehir graben from northwest (figures 3 and 4). The Kavacık fault segment extends for $8 \mathrm{~km}$ and forms a linear mountain front. Two hundred meters high scarp of this fault is occupied by short parallel drainage (figure 4). Although generally parallel and short headed, they rarely evolve into larger dendritic patterns as in the cases of the north of Kavacik and west of Istihkamlar hill, possibly due to prefaulting morphological characteristics. Unlike the Uludere segment neither significant slope breaks 


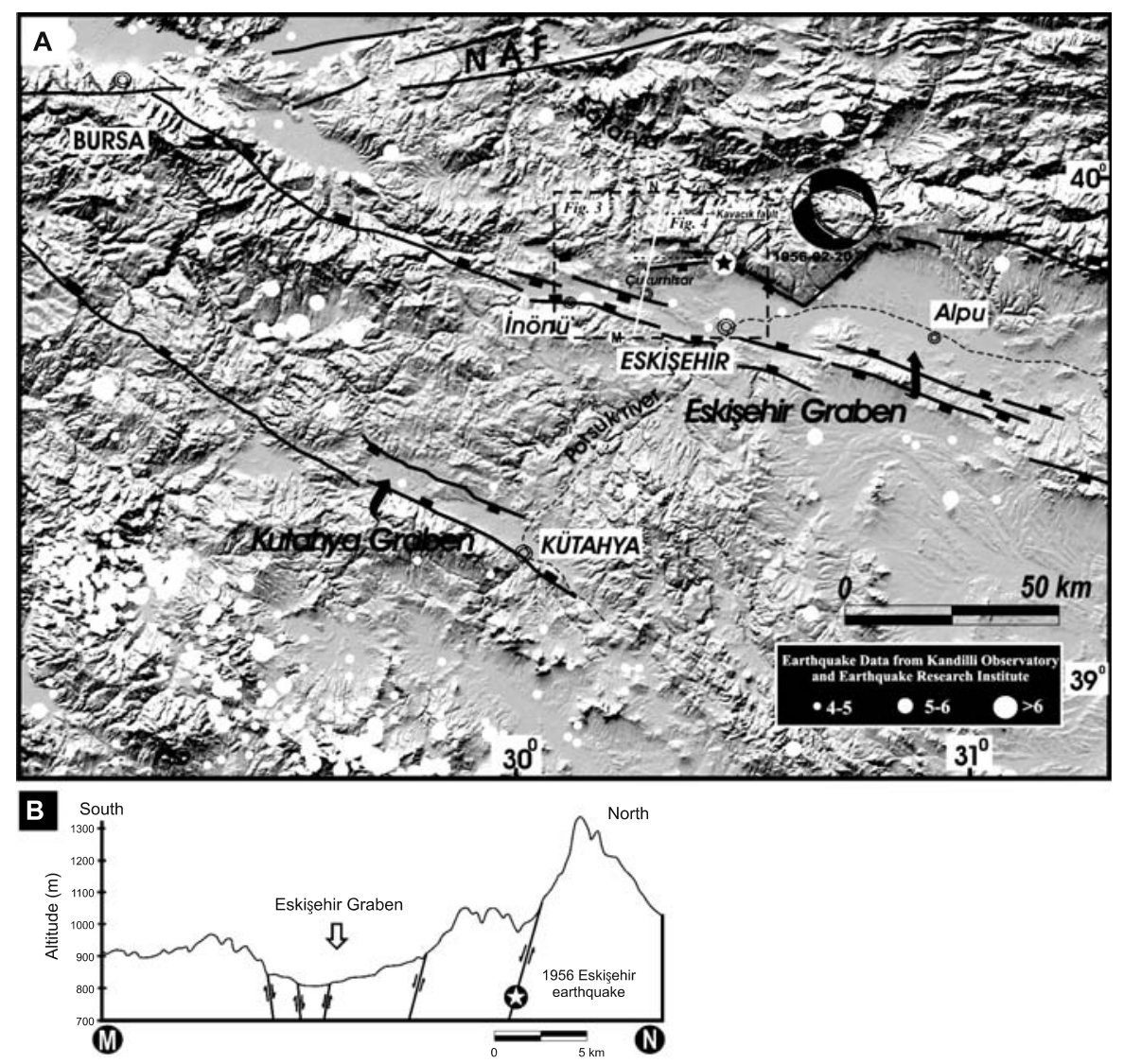

Figure 2. (A) Seismicity and active faults of the Eskişehir graben and vicinity on SRTM $90 \mathrm{~m}$ DEM (structural data from Koçyiğit 2000 and also from the author; focal solution from McKenzie 1972). (B) Topographic profile constructed across the Eskişehir graben. White solid line ending with $\mathrm{M}$ and $\mathrm{N}$ letters shows location of the profile.

nor abundant springs were observed on the Kavacik fault scarp. The Uludere segment extends for $9 \mathrm{~km}$ from west of Uludere village to the south of Karaçobanpınarı. The related mountain range of this fault segment is highly dissected by southflowing drainages. At the top of the mountain front in vicinity of the Karaçobanpinarı village, a headless paleo-valley, which is characterized by flat bottom and thick $(>130 \mathrm{~cm})$ brick-red soil is seen at an altitude of $1270 \mathrm{~m}$ (figure 4). An indistinct NW-running lateral ramp links the Kavacik fault segment and the northerly Uludere fault segment (figure 4). To the north of the ramp area, another flat-bottomed headless fluvial valley (Avlamıs hanging valley) is undergoing deep erosion by the tributaries of Sakarya River (figure 4). Both paleo-valleys were previously interpreted as the relict morphology preceding the current block-faulting (Ocakoğlu et al 2005). The total vertical offset on this fault is about $300 \mathrm{~m}$, an estimate based on the altitude of prefaulting paleo-valleys on footwall and the highest altitude of the hanging wall (figure 4). Three distinct slope breaks mark the site of synthetic faults. These are secondary faults sub-parallel to the Uludere master fault (figure 4) and traceable throughout the mountain front. Along the fault traces, ridge development and manifestation of springs are common. In certain cases (as in the Gümüşlü valley and $1 \mathrm{~km}$ west of Katranca spring), the secondary drainage branches are possibly controlled locally by the east-west trending fault trace (figure 5). The northernmost synthetic fault produced clear elongated ridges and linear scarps place to place, but apparently caused no vertical offset in the Karaçobanpınarı paleo-valley.

The hanging wall of the western part of Uludere segment borders a small depression with presumably several tens of meters thick alluvial deposit. At least three individual alluvial fan bodies can be differentiated which are sourced from the Uludere fault scarp (figure 4). The upper reach of Karagöz creek, one of the northerly tributaries of the Porsuk River, currently incises the southeast part of this infill (figure 4).

\section{Surface rupture in the Gümüşlü valley}

Some older residents (16 to 20 years old when the 1956 Eskişehir earthquake occurred) from the Uludere village reported to the authors that they 


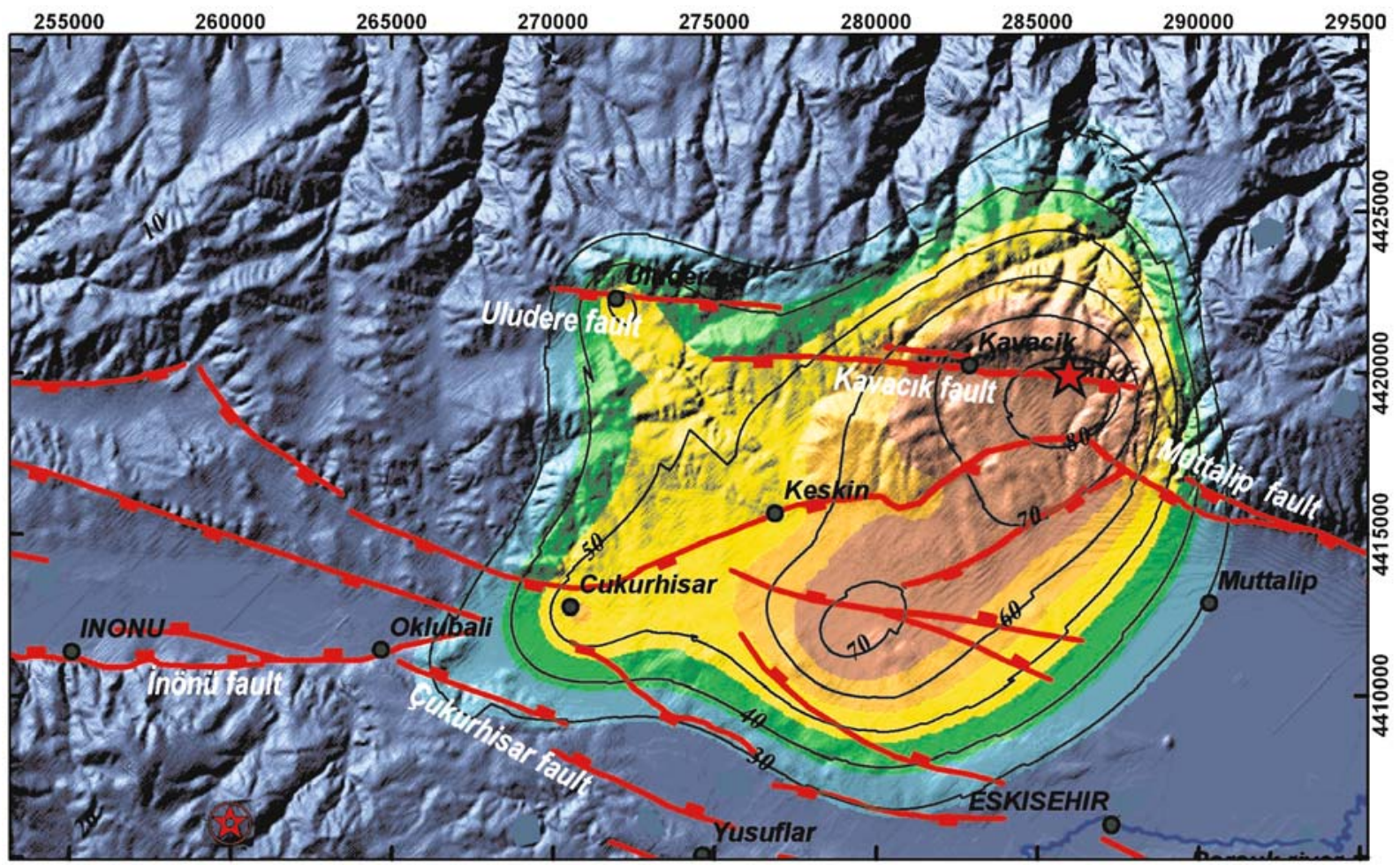

Figure 3. Distribution of damage pattern (heavy + moderate/total) of buildings related to 1956 Eskişehir earthquake (data from Öcal 1959 and Ocakoğlu et al 2006). The intensity scale used is Mercalli-Cancani-Sieberg. Digital shaded base map is produced from $1 / 25.000$ scale topographic map of $10 \mathrm{~m}$ resolution. Note that the maximum damage occurs very close to epicenter located to the north of the graben. SW epicenter belongs to the biggest aftershock.

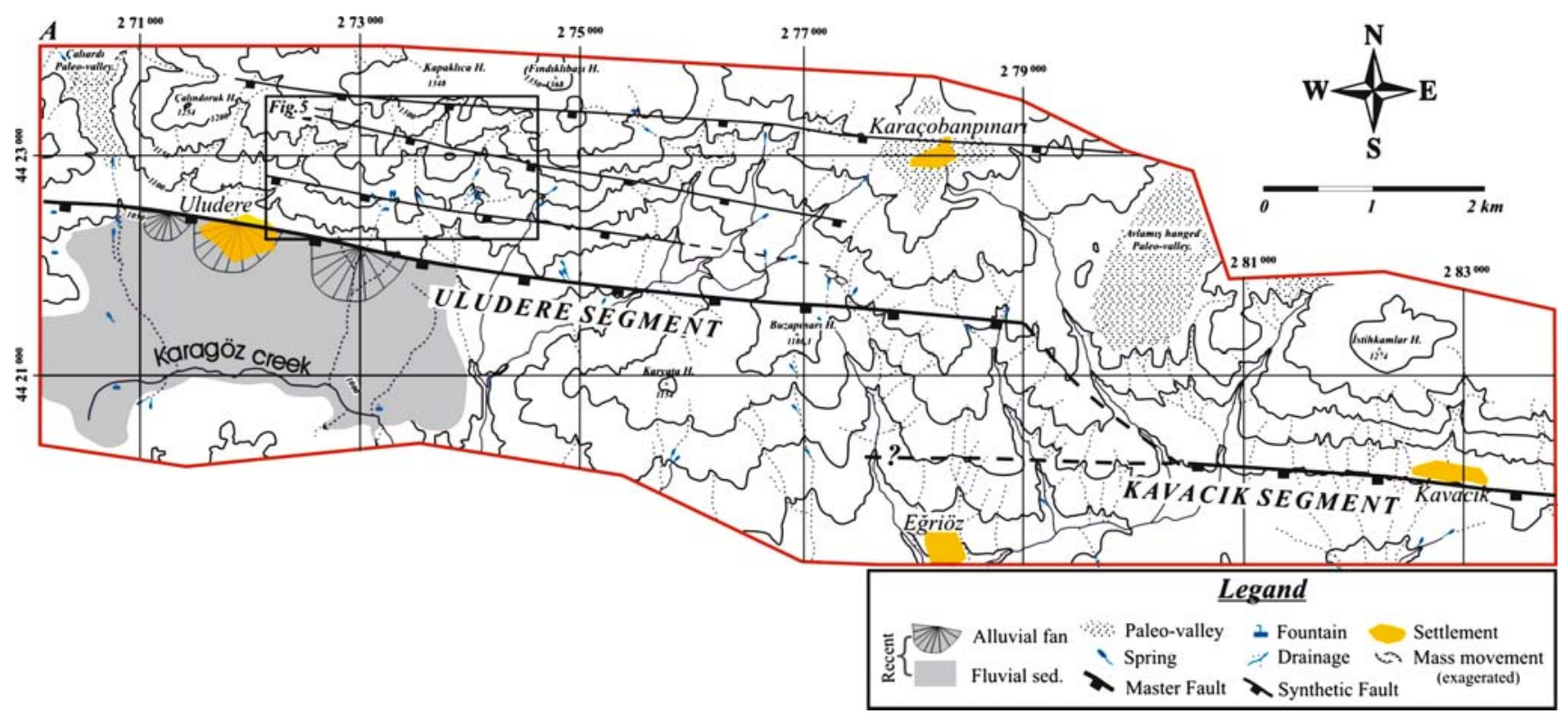

Figure 4. Morphotectonic map of the Kavacık and Uludere faults (landslides exaggerated about 5 times). Note similarly trending secondary synthetic faults to the north of Uludere segment where surface rupure is observed. Note also oblique bounding fault between Uludere and Kavacik segments.

had observed large and deep earth cracks in the Gümüşlü valley just after the 20 February 1956 Eskişehir earthquake. Since this village was heavily damaged by the earthquake (figure 3), we investigated this area. The Gümüşlü valley, named after a nearby spring is formed by one of the many south-flowing creeks, located $2 \mathrm{~km}$ east of Uludere village (figure 4). This drainage flows into 


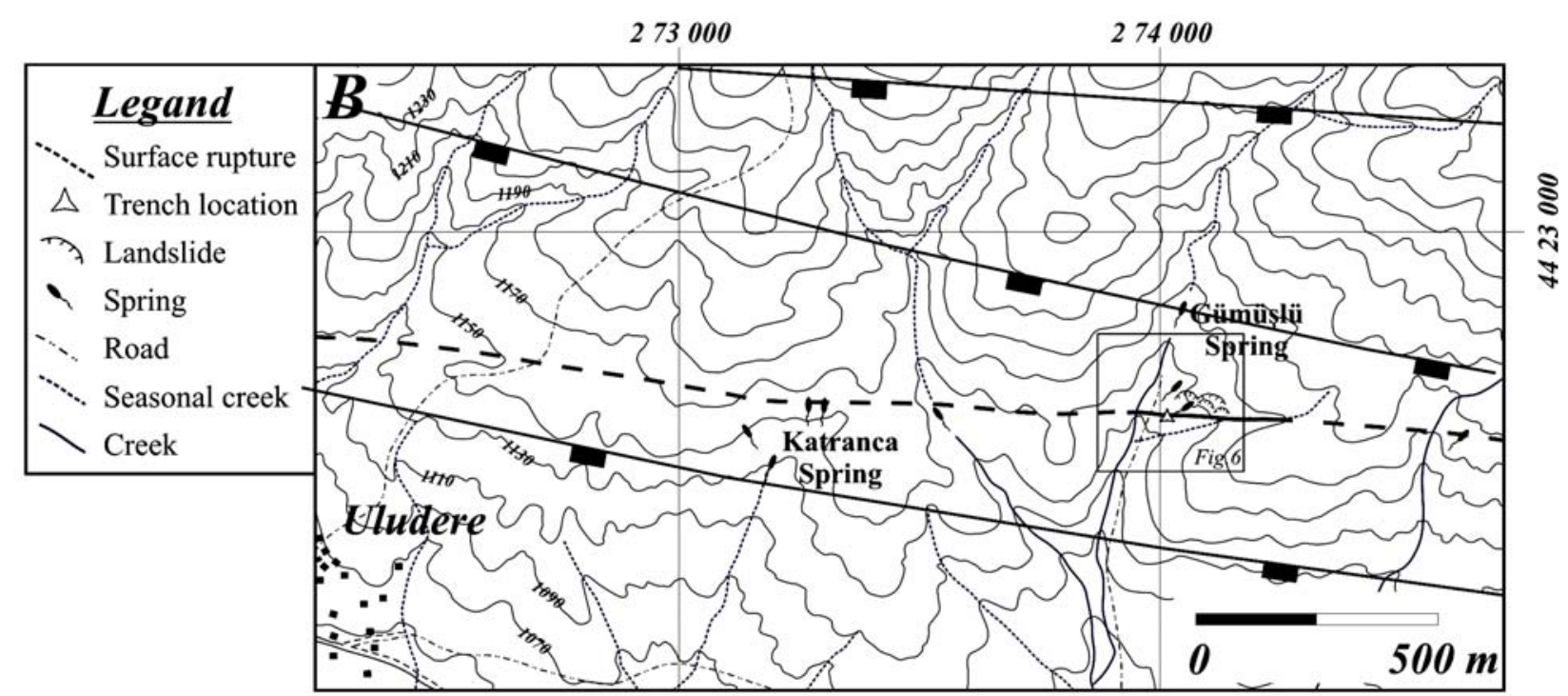

Figure 5. Detailed morphology of the Gümüşü valley and vicinity. Note that WNW-running synthetic faults define morphology, and surface rupture is grossly parallel to them.

the Uludere basin and finally joins the Porsuk River (figure 2). Certain tributaries of this drainage exhibit rectangular patterns similar to some others in the mountain front. We ascribe this feature to the weakened nature of rock material along fault trace and considerable lateral offset in the area (figure 5). Three faults can be identified by structural benches that possibly reflect the longterm uplift of the Uludere fault scarp. A structural bench is typical with its quasi-planar shape and is bounded from one side by an active fault. These structural benches are particularly preserved as elongated ridges in hanging-wall blocks at more or less the same altitude across the fault trace. Morphologically, the medial fault on the mountain front is characterized with elongated ridges and structural benches across its trace. In the north of Uludere village a sharply elongated ridge of $150 \mathrm{~m}$ wide and $200 \mathrm{~m}$ long parallel to the fault (i.e., EW) is typical (figure 5). Around the Katranca spring, a structural bench is evident and the drainage is slightly displaced left laterally (figure 5). To the $400 \mathrm{~m}$ east of Gümüşlü springs, an elongated structural bench is bordered from the north by a poorly developed fault faceta. Similarly, an elongated ridge and originally linked structural bench occur in the west of the Gümüşlü valley which is overlain with the recent alluvium at the same altitude in the eastern side of the valley (figures 5,6A). A thick marble in between the gneisses is locally tilted northwards and presumably sinistrally displaced (figure 6A). Alluvium in the Gümüslü valley is composed of relatively fine grained reddish colluvium on the slopes and dark gray organic rich materials in flat areas. At least six old looking landslide scars were mapped in the eastern slopes of the
Gümüşlü valley. We identified rock slides beneath the colluvium and in the midst of the metamorphic rocks (figure 6A). The flat lying eastern side of the valley in vicinity of the fountain exhibits various morphological features. Its southern part is slightly $\left(3-4^{\circ}\right)$ tilted to the north while the northern part rests ca. $5 \mathrm{~m}$ above through a degraded scarp with respect to southern block (figure $6 \mathrm{~B}$ ). At the foot of this scarp a spring flows out and forms a wetland in the west. It is considered that these evidences represent the long term accumulated slip on this medial fault segment like that of 1956 event.

The surface rupture of the Eskişehir earthquake crosses the eastern tilted terrace throughout for more than $100 \mathrm{~m}$ (figure $6 \mathrm{~A}$ ). It forms a $2.5 \mathrm{~m}$ wide trough that strikes $\mathrm{N} 80^{\circ} \mathrm{E}$. The height of the rupture's scarp attains $20 \mathrm{~cm}$. This fault break depression is in fact a small half graben that presumably related with a south-dipping discontinuity (figure 6B). Near the western edge of the terrace, surface rupture bifurcates, but only one branch can be traceable down the base of western slope of the terrace (figure 6A). The fault break is indistinct on the flank of western strath terrace where the slope gradients are visibly decreased (figure 6A). However, tilted marble foliations as well as collapsed blocks in thin alluvium strongly suggest that it probably extends farther west in the metamorphic basement. Towards the opposite direction (east), the surface break shows a ca. $20 \mathrm{~m}$ right-stepping and later can be faintly traceable till the metamorphic basement (figure 6A).

A trench ( $8 \mathrm{~m}$ long and $2 \mathrm{~m}$ wide) dug perpendicular to the surface rupture of the 1956 Eskişehir earthquake displays many breaks that cut the thick brownish soil and reach the surface (figure 7A, 7B). 


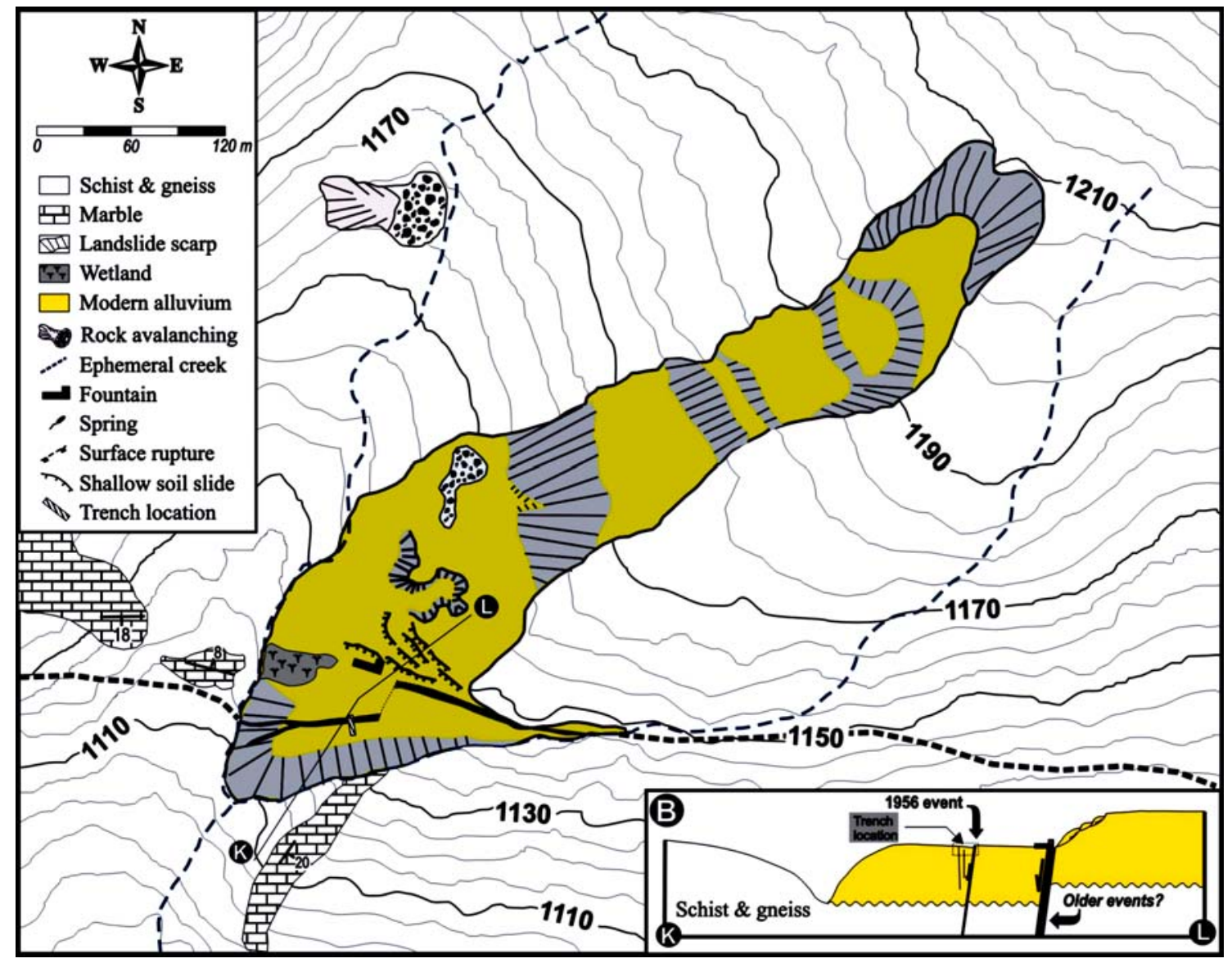

Figure 6. (A) Morphological map of the Gümüşlü valley (reproduced after 1/25.000 sheet) showing the surface rupture and older and contemporaneous landslides. (B) K-L profile across the surface rupture. Height of the slided scarp is about $3 \mathrm{~m}$.
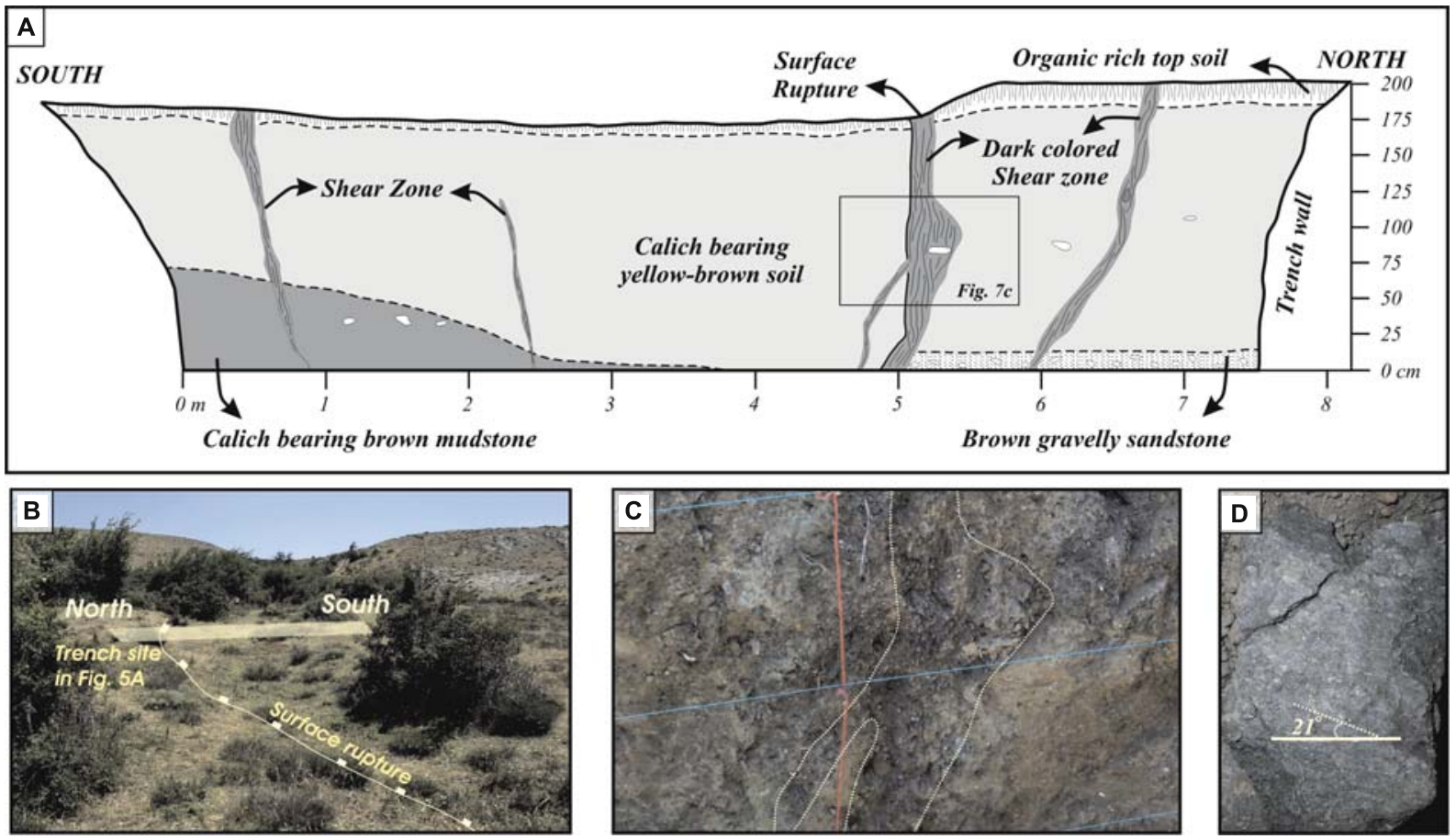

Figure 7. (A) Trench $\log$ showing the western wall of the Gümüşlü trench (width and length of the trench is about $1.5 \mathrm{~m}$ and $7.5 \mathrm{~m}$, respectively), (B) surface rupture near the trench site, (C) shear zone in the trench, and (D) slikenlines on the sheared muds in (C) (removed sample). 



Figure 8. (A) Distant view of the Gümüşlü valley. Note well-developed fault terrace. (B) Small landslides to the north of trench site at Gümüşlü valley. (C) Larger landslides at the north of Buzapınar hill (see figure 4). (D) A rockslide developed in gneisses in $2 \mathrm{~km}$ east of the Gümüşlü valley. (E) Another rockslide in steep slopes in gneisses very close to surface rupture. 
The main branch that causes the depression on the surface is a south-dipping, carbonaceous zone about $15-20 \mathrm{~cm}$ wide (figure $7 \mathrm{C}$ ). This zone displays faint shears here and there, but is limited by a clear fault from the south. Many slickensides on this fault and on secondary shear surfaces consistently indicate a trend of $\mathrm{N} 80^{\circ} \mathrm{E} / 30^{\circ} \mathrm{NE}$. Together with the surface rupture geometry (i.e., southern block down and northern block up), the orientation of slickenside clearly indicates a left lateral oblique-slip movement $\left(\right.$ rake $\left.=-30^{\circ}\right)$ (figure 7D). A parallel secondary shear-zone without any apparent surface offset is also evident, one meter to the north (figure 7A). In the south of the trench, two less distinct north-dipping shearzones occur as well. These antithetic faults did not apparently cause any displacement on the ground surface.

\section{Earthquake-triggered mass movements on the Uludere and Kavacik segments}

We observed several landslides and rockslides throughout the Uludere and Kavacik fault scarps and some of which were recognized by nearby residents just after the Eskişehir earthquake. Mass failures (meters-sized landslides) in the Gümüşlü valley follow the relatively steep scarp between tilted and horizontal terraces, and occurred as three or four stepping curvilinear lines (figures 6B, $7 \mathrm{~B}, 8 \mathrm{~B})$. Vertical offset on the small crowns of these failures is more than $1.5 \mathrm{~m}$. Another landslide belt follows the stream-eroded northern edge of the horizontal terrace. A trench at the western limit of this zone (figure 6A) did not yield any ground penetrating linear feature. For this reason we prefer a shallow landslide origin instead of surface rupture for this feature. To the $1.7 \mathrm{~km}$ southwest of Karaçobanpınarı village (figure 4) several springs form a wetland that accumulated several meters thick loose material. Slide scars (often $<1 \mathrm{~m}$ high) in these sediments are recent and may be comparable to the Gümüslü valley failures, and occur for about tens of meters in WNW-ESE direction (figure $8 \mathrm{C}$ ). One $\mathrm{km}$ east of the Gümüşlü landslides, a mappable rockslide is developed on a steep scarp of a fault terrace (figure 8D). Similarly, $250 \mathrm{~m}$ to the north of the surface rupture, another significant rockslide occurs on the steep slopes in the metamorphic rocks (figure 8E). Fresh appearance of both failures again suggests a possible connection with the 1956 Eskişehir earthquake. Lastly, $600 \mathrm{~m}$ to the northeast of Kavacık village where the damage rate was maximum (figure 3), local people reported a series of fractures on thin soil on the huge Kavacik fault scarp that would correspond to anastomosing ruptures if not shallow slides. All these lines of evidence strongly suggest that the Uludere and Kavacık areas were intensively shaken during the 1956 Eskişehir earthquake.

In addition to these fresh mass failures, eastern side of the Gümüşlü valley hosts another huge, multistoried and inactive landslide (figure 6A). It was originated at $1210 \mathrm{~m}$ altitude and moved downward for $350 \mathrm{~m}$ towards SW. Internally, six reactivation surfaces ranging in height from 2 to $10 \mathrm{~m}$ were mapped.

\section{Discussion and conclusion}

The 1956 Eskişehir earthquake $\left(M_{\mathrm{w}}=6.5\right)$ is considered as a unique damaging event on the $400 \mathrm{~km}$ long Eskişehir fault zone that occurred after the beginning of seismic instrumentations. Earlier studies of this earthquake were based on the analysis of instrumental data to obtain the position of epicenter and focal solution by Öcal (1959) and McKenzie (1972) respectively (see discussions below). Determination of the causative fault of this earthquake seems important for two interrelated reasons. First, width and trajectory of the zone is still debated particularly in the vicinity of Eskişehir city. Altunel and Barka (1998) recognized only one right-stepping zone cutting through the south of the Eskişehir graben. Earlier, researchers from Turkish Geological Survey (MTA) mapped presumably active faults to the north, within and to the south of the Eskişehir graben (Gözler et al 1984). Later work on the morphotectonics of the region generally validated this last view suggesting that the Eskişehir graben is actively subsiding by means of dominantly dip slip faults on both sides of the graben (Koçyiğit 2000, 2005; Ocakoğlu 2007; Ocakoğlu and Açıkalın 2009). Therefore, precise localization of the Eskişehir earthquake can potentially provide new insights into the fault geometry and location. Second reason addresses the seismic risk in the region. The interaction of the central Anatolian extensional structures with the north Anatolian fault zone and especially the proximity of the macroseismic epicenter of this event determined by Öcal (1959) to the Eskişehir metropolitan (population >500,000) is still a complicated problem. For these reasons, it becomes important to collect all possible data relevant to this event.

The previous empirical estimations suggest an offset up to $20 \mathrm{~cm}$ and surface rupture length of about $15-20 \mathrm{~km}$ for this magnitude of earthquake (Wells and Coppersmith 1994; Pavlides and Caputo 2004). The recent well-studied Aegean earthquakes strongly indicate that surface ruptures can be developed with even smaller magnitude earthquakes in relatively thin western 
Anatolian crust. For instance, 2002 Çay earthquake $\left(M_{\mathrm{w}}=6.5\right)$ occurred on the grossly NW-trending Akşehir fault zone (SW central Anatolia) and produced east-west to northwest-southeast running $5 \mathrm{~km}$-long surface ruptures (Koçyiğit et al 2002). The 1995 Dinar earthquake $\left(M_{\mathrm{w}}=6.2\right)$ in the east Aegean region of Anatolia occurred at $10-15 \mathrm{~km}$ focal depth and caused $10 \mathrm{~km}$ long discontinous surface rupture that consists of nearly vertical cracks up to several tens of meters long and a meter wide (Koral 2000).

Although formation of surface rupture can be expected from the above suggestions, no significant field data was provided for the 1956 Eskişehir earthquake until now. Altunel and Barka (1998) mentioned a $1 \mathrm{~m}$ high topographic break in the south of Chukurhisar where the damage was the most. Koçyiğit (2005) supported this view by considering the consistency of his slip measurements in the Inönü area and the focal solution of the 1956 Eskişehir earthquake. Şaroğlu et al (2005) favoured the İnönü fault zone as the source fault of the Eskişehir earthquake. Contrary to these earlier views, Açıkalın and Ocakoğlu (2005) determined the damage pattern of this earthquake (i.e., percent of buildings affected) and drew attention to the highly damaged (and even abandoned) villages built on the stiff metamorphic basement in the north of the graben (figure 3). Later Ocakoğlu et al (2006) used attenuation equations bringing out the significant correlation between the damage pattern and the intensity of ground shake, suggesting the association of the Kavacik fault located to the north of the graben (figure 3). The finding of surface rupture in the Gümüşlü valley and a number of mass failures in vicinity of the Uludere and Kavacik segments are further evidence of the 1956 Eskişehir earthquake.

Earthquake-triggered mass movements may occur at great distances from epicenter depending on the surface geology like the presence of loose and saturated materials (Keefer 1984). Nevertheless, certain mass movements, particularly soil slides, rock slides and rock avalanches require more intense shaking which is more likely in the vicinity of the epicenter (Keefer 1984). Probably for this reason, soil and rock slides are more common in the close proximity to the discontinuous secondary surface rupture in the Gümüşlü valley. Accordingly, ground accelerations calculated from attenuation equations for the Kavacik fault was estimated to be generally higher in the Kavackk area (Ocakoğlu et al 2005). Recent earthquake-triggered landslides in Anatolia and other Asian regions generally show close spatial relation to surface ruptures. For instance, June 6, 2000 Orta earthquake $\left(M_{\mathrm{d}}=5.9\right)$ in north central Anatolia occurred in relation to a
$\mathrm{N}-\mathrm{S}$ running oblique-slip fault, and caused intense landsliding (or re-activation of older landslides) in the area close to the source fault (Emre 2000). Similarly, landsliding or reactivations on older mass failures during the 1999 Kocaeli earthquake (NW Anatolia) were mostly observed within the tectonic valley itself (Duman et al 2005). In the 2005 Kashmir earthquake in the NW of Himalaya, the Muzafarabad and Tanda fault caused various types of surface ruptures and the related landslides were also concentrated and or followed the surface rupture (Jayangondaperumal and Thakur 2008).

Although overall context of the discovered secondary surface rupture (i.e., its position at the toe of a larger older mass movement) and its association with many small mass failures may invite a sliding origin due to ground shaking during the quake, this view is not tenable when considered in the context of the detailed morphology of the Gümüşlü valley along the sense of oblique motion obtained from slickensides (figure 7D). A right lateral oblique slip movement is expected if a pure gravity sliding origin was the case, since the south and west sides of the translated mass are free (figure $6 \mathrm{~A}$ ).

Nevertheless, there are still some discrepancies and inexplicable points in regard to limited extend of the surface rupture and particularly its position. Our investigations at both ends of the rupture in metamorphic basement around Gümüşlü valley showed only indistinct trace of vertical displacement. In the close north-east of the Kavacik village, older residents of the village reported some discontinous open cracks in metamorphic basement which are probably indistinct expression of surface rupture in this event (Ocakoğlu et al 2005). A similar situation was encountered in the June 6, 2000 Orta earthquake, which produced no apparent surface rupture in north central Anatolia. Emre (2000) observed many fissures parallel to the causative source fault. Additionally he also mapped some discontinuous surface ruptures as long as $300 \mathrm{~m}$ and stepping fractures developed on smooth alluvium very close to the geological fault. In the case of 2005 Kashmir earthquake event in the Indus Kohistan seismic zone (IKSZ) of NW Himalaya, the lenght of secondary ground fractures attains in some cases to $2.5 \mathrm{~km}$ (Thakur et al 2006).

In light of these observations it is suggested that surface rupture of the 1956 earthquake has an indistinct discontinuous pattern developed on the stiff metamorphic rocks of Uludere and Kavacık faults scarps. Anastomosing branches probably merge together but still remain indistinct, unless relatively thick loose materials overlying them accentuate the vertical slip.

The inferred surface rupture in the Gümüşlü valley displays a significant disagreement with the 
Table 1. Stress tensor directions based on the surface rupture of the 20 February 1956 Eskişehir earthquake (this work) and the focal solution (Kiratzi 2002), and the corresponding tentative rupture geometry.

\begin{tabular}{|c|c|c|c|}
\hline & & Surface rupture & Focal solution \\
\hline \multirow[t]{3}{*}{ Nodal plane 1} & Strike & 80 & 141 \\
\hline & Dip & 83 & 57 \\
\hline & Rake & -30 & -5 \\
\hline \multirow[t]{9}{*}{ Nodal plane 2} & Strike & & 264 \\
\hline & Dip & & 50 \\
\hline & Rake & & -135 \\
\hline & $\mathrm{Az}$ & 24 & 108 \\
\hline & $\mathrm{Pl}$ & 21 & 57 \\
\hline & $\mathrm{Az}$ & 132 & 204 \\
\hline & $\mathrm{Pl}$ & 38 & 4 \\
\hline & & $\frac{\text { Uludere }}{\text { segment }} \leftrightarrows$ & \\
\hline & & & $\frac{n i n}{\text { nent }}$ \\
\hline
\end{tabular}

results of focal solutions of the 1956 Eskişehir earthquake given by McKenzie (1972) and in some unpublished data (Kalafat 2006, personal communication). Both authors suggest a slightly leftlateral dip-slip movement on a $\mathrm{N} 30^{\circ} \mathrm{W}$-trending, $60^{\circ} \mathrm{SW}$-dipping plane, and right-lateral dip slip movement on an auxiliary east-west running, $50^{\circ}$ north-dipping plane (table 1 ). Although the Gümüslü valley surface rupture fits well in direction $\left(\mathrm{N} 80^{\circ} \mathrm{E}\right)$ with the latter plane, the sense and measure of the dip (i.e., $83^{\circ} \mathrm{SW}$ ) do not. On the other hand, Kiratzi (2002) re-evaluated the McKenzie's focal solution in the light of larger stress data from westernmost north Anatolian fault zone and the Aegean region. She inferred the NWrunning and SW-dipping surface as the oblique-slip rupture plane for the 1956 Eskişehir earthquake (table 1). In agreement with her, we choose the second (SW dipping) plane as the failure plane. But in this case it is difficult to explain stress solution (table 1) based on strike and pitch of the surface rupture. Although this situation could be partially explained by the distorted slip measurements in semi-consolidated soil, it may be more reasonable to suggest an arc-shaped plan view of the surface rupture, i.e., grossly $\mathrm{E}-\mathrm{W}$ running in the western tip and NW-running in the southeastern part. This NW-trending part probably correspond the lateral ramp between Uludere and Kavacik segments where the earthquake was originated (table 1). A second alternative is that the first motion would have occurred on the westernmost tip of the $\mathrm{N} 65^{\circ} \mathrm{W}$ running Muttalip fault very close to instrumental epicenter (figure 3). This interpretation somewhat agrees with the focal solution of Kiratzi (2002) as well. Then the main rupture could have occurred on the NW-running main segment of the Muttalip fault and extended westward until the Uludere fault segment with some directional changes due to pre-existing geological structures (figure 3). In that case, the observed surface rupture in the Gümüslü valley would represent the northwestern tip of this surface rupture.

\section{Acknowledgements}

This paper is realized in the frame of the research project (No: 200315023) 'Tectono-stratigraphic and sedimentologic evolution of the Eskişehir region during the neotectonic period' funded by the Commission for the Scientific Research Projects of the Eskişehir Osmangazi University. The authors thank Dr Tekin Yürür (Hacettepe University) for his constructive comments, and encouraging to publish the observations. Dr Cenk Yaltırak (Istanbul Technical University) helped with the rupture data and regional geology. Dr Kadir Dirik (Hacettepe University) carried out the stress analysis of the slip data. Authors sincerely acknowledge their valuable contributions. 


\section{References}

Açıkalın S and Ocakoğlu F $2005 \quad 20$ Şubat 1956 Eskişehir Depremi Hangi Faydan Kaynaklanış Olabilir?; Eskişehir Fay Zonu ve İlişkili Sistemlerin Depremselliği Çalıştayı Bildiriler Kitabı 28-30 Nisan 2005 Eskişehir [in Turkish].

Altunel E and Barka A 1998 Eskişehir Fay Zonu'nun InönüSultandere arasındaki neotektonik aktivitesi; Türkiye Jeoloji Bülteni 2 41-52 [in Turkish with English abstract].

Bozkurt E 2001 Neotectonics of Turkey - A synopsis; Geodinamica Acta 14 3-30.

Duman T Y, Çan T, Emre Ö, Keçer M, Doğan A, Ateş Ş and Durmaz S 2005 Landslide inventory of northwest Anatolia Turkey; Engineering Geology 77 99-114.

Emre Ö 200006 Haziran 2000 Orta (Çankırı) Depremi Değerlendirme Raporu; MTA Rapor No: 10323 [in Turkish].

Gözler M Z, Cevher F and Küçükayman A 1984 Eskişehir civarının jeolojisi ve sıcak su kaynakları; MTA Dergisi 103 40-54 [in Turkish].

Jayangondaperumal R and Thakur V C 2008 Co-seismic secondary surface fractures on southeastward extension of the rupture zone of the 2005 Kashmir earthquake; Tectonophys. 446(1-4) 61-76.

Kahle H G, Straub C, Reilinger R, Mcclusky S, King R, Hurst K, Veis G, Kastens K and Cross P 1998 The strain rate field in the eastern Mediterranean region estimated by repeated GPS measurements; Tectonophys. 294 237-252.

Keefer D K 1984 Landslides caused by earthquakes; Geol. Soc. Am. Bull. 95 406-421.

Kiratzi A 2002 Stress tensor inversions along the western north Anatolian fault zone and its continuation into the North Aegean Sea; Geophys. J. Int. 151 360-376.

Koçyiğit A 2000 Orta Anadolu'nun genel neotektonik özellikleri ve depremselliği; Haymana-Tuzgölü-Ulukışla Basenleri Uygulamalı Çalışma (WORKSHOP) TPJD Özel Say 5 1-26 [in Turkish with English abstract].

Koçyiğit A 2005 The Denizli graben-horst system and the eastern limit of western Anatolian continental extension: Basin fill structure deformational mode throw amount and episodic evolutionary history SW Turkey; Geodinamica Acta 18(3-4) 167-208.

Koçyiğit A, Bozkurt E, Kaymakçı N and Şaroğlu F 20023 Şubat 2002 Çay (Afyon) Depreminin Kaynağ ve Ağır hasarın nedenleri: Akşehir Fay Zonu; Orta Doğu Teknik Üniversitesi Tektonik Araştırma Birimi, Ön Rapor, pp. 17 [in Turkish].

Koral H 2000 Surface rupture and rupture mechanism of the October 1, $1995\left(M_{\mathrm{w}}=6.2\right)$ Dinar earthquake, SW Turkey; Tectonophys. 327(1-2) 15-24.
McKenzie D P 1972 Active tectonics of the Mediterranean Region; Geophys. J. R. Astron. Soc. 30 109-185.

Ocakoğlu F, Altunel E and Yalçıner Ç 2005 Eskişehir bölgesinin neotektonik dönemdeki tektono-stratigrafik ve sedimantolojik gelişimi; Osmangazi Üniversitesi Bilimsel Araştırma Projeleri Komisyonu Final Raporu 122 p [in Turkish with English abstract].

Ocakoğlu F, Açıkalın S, Gökçeoglu C, Nefeslioglu H A and Sönmez H 2006 Back-analysis of source fault identification by using attenuation equation and damage data: February 201956 Eskişehir Earthquake (NW Anatolia Turkey) example; Bull. Eng. Geol. Environ. 66(3) 353-360.

Ocakoğlu F 2007 A re-evaluation of the Eskişehir Fault Zone as a recent extensional structure in NW Turkey; J. Asian Earth Sci. 31 91-103.

Ocakoğlu F and Açıkalın S 2009 Late Pleistocene faultinduced uplift and consequent fluvial response in Eskişehir Fault Zone NW Anatolia; Zeitschrift Fur Geomorphologie 53(1) 121-136.

Okay A I, Satır M, Zattin M, Cavazza W and Topuz G 2008 An Oligocene ductile strike-slip shear zone: Uludağ Massif northwest Turkey - implications for the escape tectonics; Geol. Soc. Am. Bull. 120 893-911.

Öcal N 195920 Şubat 1956 Eskişehir Zelzelesinin Makrove Mikrosismik Etüdü; İTÜ Sismoloji Enstitüsü Yayını 49 p [in Turkish].

Özsayın E and Dirik K 2007 Quaternary activity of the Cihanbeyli and Yeniceoba Fault Zones: Inönü-Eskişehir Fault System Central Anatolia; Turkish J. Earth Sci. 16 471-492.

Pavlides S and Caputo R 2004 Magnitude versus fault's surface parameters: Quantitative relationships from the Aegean Region; Tectonophys. 380(3-4) 159-188.

Şaroğlu F, Emre Ö, Doğan A and Yıldırım C 2005 Eskişehir Fay Zonu ve Deprem Potansiyeli; Eskişehir Fay Zonu ve İlişkili Sistemlerin Depremselliği Çalıştayı Bildiri Özleri Kitabı s 11 [in Turkish].

Thakur V C, Jayangondaperumal R, Champatiray P K, Bhat M I and Malik M A 20068 October, 2005 Muzaffarabad earthquake and seismic hazard assessment of Kashmir Gap in northwestern Himalaya; J. Geol. Soc. India 68(2) 187-200.

Tokay F 2001 Neotectonic features of the İnönü-Dodurga segment of the Eskişehir Fault Zone; Eskişehir Osmangazi University MSc Thesis, 67 pp [in Turkish with English abstract].

Wells D L and Coppersmith K J 1994 New empirical relationships among magnitude rupture length surface width rupture area and surface displacement; Bull. Seismol. Soc. Am. 84(4) 974-1002.

Yaltırak C 2002 Tectonic evolution of the Marmara Sea and its surroundings; Marine Geol. 190 493-529. 